\title{
PARIWISATA DAN EKSISTENSI PENDIDIKAN AGAMA DALAM BINGKAI BUDAYA PULAU DEWATA (Analisis Dampak Sektor Pariwisata terhadap Pendidikan Agama Masyarakat Denpasar Bali)
}

\author{
Ketut Wardhana \\ Lembaga Penelitian Institut Hindu Dharma Negeri Denpasar Bali \\ Amir Fadhilah \\ Universitas Islam Negeri (UIN) Syarif Hidayatullah Jakarta \\ Email:ketut_wardana@gmail.com
}

\begin{abstract}
The development of tourism in Bali has caused structural changes from agrarian economy into a service economy. The positive impact of the tourism sector, among others, increasing the living standards of the people, especially those in the field that has to do with tourism. Infrastructure development in various regions of Bali is directed to facilitate transportation and communication between regions. While the negative impact that arises is the commercialization, commodification, and profanation, the traditions and customs remain well-preserved through the implementation of a religious ritual (yajna) in everyday life. This condition is a process of dynamic equilibrium, ie the awareness of the people of Bali to constantly adapt and tolerate what happens outside, but on the other band they aware that they are to keep their tradition.
\end{abstract}

Keywords: tourism, cultural, religious rituals

\begin{abstract}
Abstrak
Pembangunan kepariwisataan di Bali menyebabkan perubahan struktur ekonomi agraris menjadi ekonomi jasa. Dampak positif sektor pariwisata antara lain meningkatnya taraf hidup masyarakat, terutama yang bergerak di bidang yang ada hubungannya dengan kepariwisataan. Pembangunan infrastruktur di berbagai wilayah Bali diarahkan untuk memperlancar transportasi dan komunikasi antarwilayah. Dampak negatif yang muncul adalah terjadinya komersialisasi, komodifikasi, dan profanisasi. Meskipun demikian, tradisi dan adat-istiadat tetap terpelihara melalui pelaksanaan ritual keagamaan (yajna) dalam kehidupan sehari-hari. Kondisi ini merupakan suatu proses dynamic equilibrium, yaitu adanya kesadaran pada masyarakat Bali untuk senantiasa beradaptasi dan toleransi dengan pihak luar, namun di sisi lain ada kesadaran untuk tetap mempertahankan tradisinya.
\end{abstract}

Kata kunci: pariwisata, budaya, ritual keagamaan

\section{A. Pendahuluan}

Salah satu tekat bangsa Indonesia dalam pendidikan adalah bahwa melalui pendidikan setiap warga masyarakat Indonesia dibina dan ditingkatkan keimanannya terhadap Tuhan Yang Maha Esa, sehingga salah satu unsur tujuan pendidikan nasional adalah adanya peningkatan iman dan keyaqwaan kepada Tuhan Yang Maha Esa. Di sinilah letak fungsi pendidikan agama sebagai bagian dari unsur pendidikan nasional.

Sektor pariwisata Bali juga tidak lepas dari pengaruh lembaga keuangan dunia. Rencana besar Bank Dunia untuk mengintegrasikan Bali ke dalam industri tourism internasional memang tidak bisa terlaksana sampai awal 1970-an. Ia harus menunggu sampai Presiden Soekarno yang sangat anti modal asing turun dari kekuasaanya pada era 1965. Memasuki era Orde Baru pembangunan infrastruktur yang diperlukan dilaksanakan secara cepat dan besarbesaran. Dimulai dengan peresmian Bandara Internasional Ngurah Rai pada 1969, pendirian fasilitas pelayanan, terutama hotel dan restoran, berusaha mengimbangi serbuan wisatawan yang 
berlipat 20 kali dalam waktu 10 tahun.

Sesuai dengan master plann Bank Dunia, yang menjadi target utama pengembangan industri tourism ini adalah wilayah Sanur, Kuta, Nusa Dua, Ubud, dan hanya sebagian kecil dari ujung Selatan Pulau Bali. Namun, seiring dengan pesatnya gerak modal yang berputar di wilayah tersebut, seluruh sel kehidupan masyarakat Bali dirangsang untuk mendukung kelangsungannya. Kalau di atas kertas rencana Bank Dunia memberi kesan rakyat Bali bisa memilih apa yang ingin mereka jual dan tidak, dalam kenyataannya pilihan itu berada di tangan pasar internasional. ${ }^{1}$ Kalau kita perhatikan secara seksama, proposal Bank Dunia 2000 merupakan bagian dari paket penyesuaian struktural di bidang kebudayaan yang disodorkan oleh IMF dan lembaga keuangan internasional lainnya.

Masalah lain yang tidak kalah pentingnya terlihat dalam rencana institusionalisasi agama Hindu melalui pendirian desa-desa adat. Sejak Bali dibuka sebagai wilayah internasional penduduknya menjadi sangat beragam, baik dari segi ras, etnis, maupun agama. Upaya menghindukan Bali dengan sendirinya akan mengasingkan mereka yang tidak beragama Hindu, dan yang lebih membahayakan lagi, mempertebal prasangka terhadap kelompok lain yang tidak mendukung proyek ini. Padahal, dalam sejarahnya agama Hindu di Bali bersifat sangat terbuka terhadap interpretasi dan tidak mempersoalkan ketepatan tata cara menurut kitab suci seperti halnya agama-agama Samawi.

Di penghujung abad ke-20, apa yang disebut "ekses negatif tourism" semakin tampak jelas sampai taraf mengganggu kenyamanan wisatawan itu sendiri. Meskipun beberapa analis masih bertahan dengan argumennya bahwa pendapatan dari tourism telah meningkatkan rasa percaya diri orang Bali terhadap tradisinya, bahkan mendorong "renaisans kultural', kenyataan menunjukkan gejala dekadensi kebudayaan yang cukup parah. ${ }^{2}$ Ancaman yang semula dianggap rekaan di atas kertas belaka menjadi persoalan riil. Upaya sporadis mempromosikan bentuk-bentuk tourism alternatif, seperti ekotourism, tidak mampu

1 Ambara Alit. 2001. Proyek Bank Dunia Mem-Bali-Kan Bali, http:// mkb.kerjabudaya.org/mkb-052001/mkb-sisipan-052001/sisipan-3-052001.html. (diakses tanggal 1 Juni 2006) berpacu dengan degradasi lingkungan hidup di Pulau Dewata.

Langkah-langkah guna menunjang usaha kepariwisataan antara lain melalui pengembangan objek wisata serta kegiatan produksi barang kerajinan untuk cindera mata, di samping tetap menjaga stabilitas keamanan dan menjaga kelestarian lingkungan hidup. Berdasarkan Perda Propinsi Tingkat I Bali No.14 tahun 1989, sebagian urusan pemerintahan dalam bidang kepariwisataan telah diserahkan pada Daerah Tingkat II yang meliputi: (1) urusan obyek wisata, sepanjang yang tidak menjadi urusan pemerintah pusat dan pemerintah daerah tingkat I Bali, (2) urusan usaha rekreasi dan hiburan umum, kecuali disco dan rekreasi air, (3) urusan perkemahan dan mandala wisata, dan (4) urusan promosi di dalam wilayah.

Potensi yang mampu menunjang berkembangnya kepariwisataan adalah: (1) tatacara kehidupan masyarakat (way of life), kesucian, upacara agama, adat istiadat yang kesemuanya berlandaskan ajaran agama Hindu, (2) keindahan alam, bangunan bersejarah dan arsitektur Bali, (3) sarana dan fasilitas yang memadai sampai bertaraf internasional. ${ }^{3}$ Fenomena yang menarik dalam konteks ini adalah bahwa pariwisata di Bali selalu dikaitkan dengan ranah pendidikan agama terutama tata cara kehidupan masyarakat (way of life), kesucian, upacara agama, adat istiadat yang kesemuanya berlandaskan ajaran agama Hindu sebagai salah satu kebijakan pemerintah setempat. Dalam konteks ini ada upaya untuk mensinergikan antara pendidikan agama dan pengembangan sektor pariwisata dalam bingkai budaya lokal. Kondisi demikian merupakan fenomena yang menarik untuk dikaji lebih mendalam melalui suatu kajian (penelitian) tentang eksistensi pendidikan agama pada sektor pariwisata dalam bingkai budaya lokal.

\section{B. Kerangka Konseptual Analisis}

Pasal 3 UU Nomor 20 Tahun 2003 menyatakan bahwa pendidikan nasional berfungsi mengembangkan kemampuan dan membentuk watak serta peradaban bangsa yang bermartabat dalam rangka mencerdaskan 
kehidupan bangsa, bertujuan untuk berkembangnya potensi peserta didik agar menjadi manusia yang beriman dan bertakwa kepada Tuhan Yang Maha Esa, berakhlak mulia, sehat, berilmu, cakap, kreatif, mandiri, dan menjadi warga negara yang demokratis serta bertanggung jawab. Dalam hal ini, peran serta tokoh agama dan tokoh adat di masyarakat memiliki karakteristik tersendiri.

Mengacu pada beberapa penelitian sebelumnya peran tokoh agama sebagai pendidik masyarakat, dan tokoh adat sebagai pemegang lembaga adat berperan sebagai organisator, yaitu sebagai pemangku adat yang mendamaikan warganya yang berselisih. ${ }^{4}$ Tokoh agama juga berperan sebagai tokoh yang mendinamisasi aktivitas sosial politik masyarakat, ${ }^{5}$ tokoh agama berperan sebagai pemimpin gerakan anti kolonial, ${ }^{6}$ tokoh agama berperan sebagai katalisator, yaitu pihak yang mampu mempengaruhi perubahan ke arah kemajuan. ${ }^{7}$ Tokoh agama (kyai) berperan juga sebagai pendidik (informator), pemimpin pengikutnya, pengobatan alternatif, pengurus partai politik, peran advokatif, yaitu mengontrol masyarakat, ahli ilmu agama (legitimator), pembimbing dan penasehat umat (motivator), volunter, yaitu sukarelawan yang mampu berperan aktif dan kreatif dalam menyeleksi nilai-nilai dan sikap yang berkembang di masyarakat. ${ }^{8}$

Karakteristik personal dan peran sosial tersebut akan membentuk dan mendorong terbentuknya peran tokoh agama dan tokoh adat di masyarakat sebagai informator, yaitu selaku tokoh umat yang aktivitasnya tidak lepas dari kegiatan mengajar dan mendidik pengikutnya yang ada di lingkungan sekitarnya, peran ini menunjukkan bahwa tokoh agama berperan sebagai pengajar dan pendidik masyarakat yang melakukan transformasi pengetahuan yang dimilikinya. Dengan kata lain, tokoh agama dan tokoh adat memiliki posisi sebagai pemberi fatwa yang sekaligus berperan sebagai legitimator

\footnotetext{
4 Ismuha dkk. 1996. Ulama Aceh dalam Perspektif Sejarah (dalam buku Agama dan Perubaban Sosial oleh Taufik A. (ed). Jakarta: PT Raja Grafindo.

5 Jackson Karl D. 1990. Kewibawaan Tradisional. Islam dan Pemberontakan - Kasus Darul Islam Jawa Barat. Jakarta: Pustaka Utama Grafiti.

6 Kurasawa Aiko. 1993. Mobilitas dan Kontrol Sosial: Studi Tentang Perubahan Sosial di Pedesaan Jawa 1942-1945 (terjemahan dari Mobilization and Control oleh Hermawan Sulistyo). Jakarta: PT Gramedia Widiasarana Indonesia Horikoshi, Hiroko. 1987. Kyai dan Perubahan Sosial. Jakarta: Perhimpunan Pengembangan Pesantren dan Masyarakat (P3M).

8 Fadhilah, A. 2005. Budaya Politik Kyai di Pedesaan : Studi Kasus Kyai Pesantren di Kabupaten Pekalongan. Tesis Program Studi Sosiologi Pedesaan Sekolah Pascasarjana IPB.
}

berdasarkan landasan agama dan norma-norma adat yang berlaku di masyarakat. Posisi yang demikian mendorong tokoh agama dan tokoh adat menjadi tokoh panutan yang memberikan tuntunan dan contoh secara langsung kepada masyarakat, yang dapat mempengaruhi dan mendorong masyarakat untuk terlibat dalam berbagai kegiatan di masyarakat. Dalam konteks ini tokoh agama dan tokoh adat dapat dikatakan sebagai motivator yang mampu membimbing masyarakat. Di sisi lain tokoh agama dan tokoh adat dapat berperan sebagai penyaringpenyaring nilai-nilai yang masuk ke masyarakat, sehingga tokoh agama dan tokoh adat juga memiliki peran sebagai katalisator.

Karakteristik personal yang berbeda antara tokoh agama dan tokoh adat yang satu dengan lainnya, akan memunculkan pola peran tokoh agama dan tokoh adat dalam upaya untuk mensinergikan antara pendidikan agama dan pengembangan sektor pariwisata dalam bingkai budaya lokal. Dengan demikian secara ringkas kerangka konseptual penelitian ini dapat digambarkan pada berikut ini..

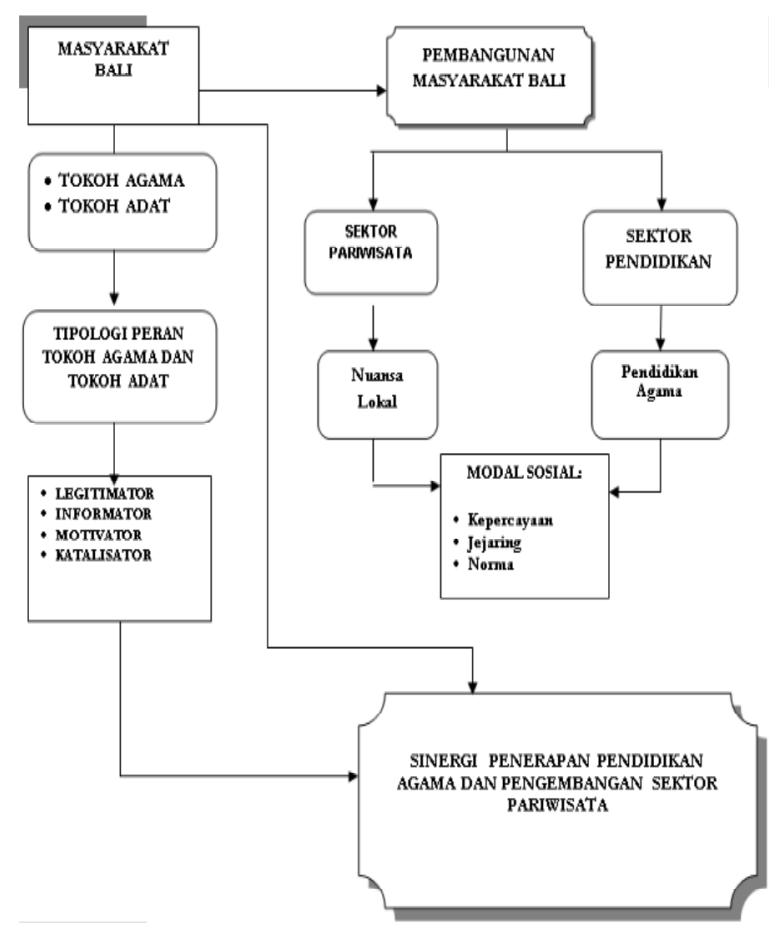

Gambar 2. Kerangka Konseptual Penelitian

\section{Eksistensi Pendidikan Agama dalam Konteks Budaya Lokal Bali}

Agama telah berperan sebagai pemersatu aspirasi manusia yang paling sublim, sebagai sejumlah besar moralitas, sumber tatanan 
masyarakat dan perdamaian batin individu, sebagai sesuatu yang memuliakan dan yang membuat manusia beradab. ${ }^{2}$ Di sisi lain, Durkeim memandang agama sebagai suatu sistem kepercayaan yang disatukan oleh praktikpraktik yang bertalian dengan hal-hal suci, yakni sesuatu yang diperbolehkan dan sesuatu yang dilarang, kepercayaan dan praktik-praktik tersebut mempersatukan mereka. ${ }^{10}$ Dengan kata lain, agama selalu meliputi seperangkat ritual atau praktik maupun seperangkat kepercayaan, dan kepercayaan ritual itu terorganisasi secara sosial dan diberlakukan oleh anggota-anggota suatu masyarakat. ${ }^{11}$

Masyarakat Hindu di Bali dalam kehidupan sehari-harinya selalu berpedoman pada ajaran agama Hindu warisan para lelulur Hindu di Bali, terutama dalam pelaksanaan upacara ritual dalam hubungan sesama dengan Tuhan, hubungan manusia dengan manusia dan hubungan manusia dengan alam. Menurut pandangan agama Hindu, dalam masyarakat diwarnai oleh sesuatu yang hidup dan kehidupan itu sendiri ditentukan oleh sumber yang memberi kehidupan. Tiga sebab terjadinya interaksi sebagai perilaku kebaikan berkisar pada: (1) hubungan manusia dengan sesamanya, (2) hubungan manusia dengan lingkungannya, dan (3) hubungan manusia dengan Tuhan Yang Maha Esa. Implementasi dan aktualisasi ketiga sumber interaksi ini dilakukan oleh masyarakat Hindu Bali melalui berbagai ritual upacara keagamaan yang biasa disebut "yajna". Kata "yajna" berasal dari kata "yaj" yang berarti memuja atau mengadakan selamatan. Jadi "yajna" berarti pemujaan suci, pengorbanan suci dengan hati yang tulus ikhlas tanpa pamrih. ${ }^{12}$ Dari sudut falsafahnya 'yajna' berarti cara melakukan hubungan antara 'atman' dan 'paramatman' antarmanusia dengan Sanghyang Widhi serta semua manifestasi-Nya dengan jalan yajna untuk memperoleh kesucian diri. Melalui pelaksanaan yajna, nilai-nilai agama disosialisasikan kepada seluruh anggota masyarakat dan sebagai salah pola pendidikan

\footnotetext{
9 Thomas F. O'dea. 1988. Sosiologi Agama: Suatu Pengenalan Awal (terjemahan dari The Sociology of Religion: oleh Tim penerjemah Yasogama). CV Rajawali: Jakarta.

10 Durkheim, Emile. 1965. The Elementery Forms of the Religious Life. New York: Free Press.

11 Sanderson Stephen K. 2000. Makro Sosiologi: Sebuab Pendekatan Terbadap realitas Sosial (terjemahan dari Makro Sosiologi oleh Farid Wajidi), Jakarta: PT Raja Grafindo.

12 Tim Penyusun PHDI. 2005. Buku Pelajaran Agama Hindu. Surabaya: Penerbit Paramita.
}

agama yang dilakukan oleh umat Hindu di Bali. Dengan kata lain, aplikasi pendidikan agama dilakukan secara langsung melalui keterlibatan dalam, pelaksanaan ritual suci (yajna).

Eksistensi pendidikan agama di masyarakat Bali tetap terpelihara dan terjaga melalui aktivitas ritual keagamaan dan budaya lokal masyarakat Bali. Kebudayaan (budaya) merupakan hasil karya, rasa, dan cipta masyarakat. ${ }^{13}$ Wujud suatu budaya meliputi 3 wujud. Pertama, wujud kebudayaan sebagai suatu kompleks dari ide-ide, gagasan, nilai-nilai, norma-norma, peraturan dan sebagainya. Kedua, wujud kebudayaan sebagai suatu kompleks aktivitas serta tindakan berpola dari manusia dalam masyarakat. Ketiga, wujud kebudayaan sebagai benda-benda hasil karya manusia. ${ }^{14}$

Mengacu pada pemaparan di atas, implementasipendidikanagama pada masyarakat Bali dapat dikatakan menyentuh seluruh wujud kebudayaan, pada wujud pertama, yaitu wujud ideal dapat kita lihat bahwa tata nilai keagamaan Hindu menjadi landasan nilai-nilai dan normanorma masyarakat Bali. Sedangkan pada wujud kedua, yaitu sebagai suatu sistem sosial dan landasan tindakan masyarakat. Implementasi ini dapat dilihat dari ajaran agama Hindu tentang susila (etika) yang menjadi landasan dalam membina hubungan antarmanusia dan mahluk lainnya. Sementara untuk implementasi dalam wujud budaya yang ketiga, yaitu bendabenda fisik. Hal yang paling mudah dilihat adalah pada arsitektur dan bangunan-bangunan suci umat Hindu, seperti: pura, candi, bale, kuil, pratima (patung yang dianggap suci di dalam pura). Plangkiran (tempat sesajen yang berada di beberapa tempat penting), serta alat-alat ritual lainnya (tempat tirta/air suci), tempat pasepan (sarana api upacara), dan lain-lain.

Nilai-nilai keagamaan teraplikasi dalam berbagai wujud kebudayaan, mengindikasikan bahwa pola pengajaran dan pendidikan agama selain didapat dari lembaga pendidikan (sekolah ataupun pasraman) masyarakat Hindu Bali peroleh dari pelaksanaan ritual dan telah menjadi norma-norma di masyarakat. Dalam konteks ini, norma-norma tersebut di atas,

13 Soemardjan, Selo dan S. Soemardi. 1964. Setangkeai Bunga Sosiologi. Jakarta : Lembaga Penerbit Fakultas ekonomi Universitas Indonesia.

14 Koentjaraningrat. 1990. Pengantar Ilmu Antropologi. Jakarta : PT Rineka Cipta. 
setelah mengalami suatu proses pada akhirnya akan menjadi bagian dari institusi masyarakat. Proses ini oleh Leopold Von Weise dan Howard Becker dinamakan sebagai proses pelembagaan (institutionalization), yaitu proses yang dilewati oleh suatu norma kemasyarakatan untuk menjadi bagian dari salah satu lembaga kemasyarakatan. ${ }^{15}$

\section{Dampak Pariwisata terhadap Kebe- radaan Budaya Lokal Masyarakat Bali}

Pasca tragedi bom I di Legian Kuta pada 12 Oktober 2002 dan bom II di Oktober 2005 berdampak pada sektor pariwisata. Berdasarkan data statistik pariwisata Bali, kalau pada tahun 2001 Bali mampu mendatangkan 1.356.774 wisatawan, pada 2002 kunjungan wisatawan menurun menjadi 1.285.844 wisatawan. Dampak dari bom Bali pertama yang sebetulnya terjadi 2002, sangat keras dirasakan pada 2003 dengan kunjungan wisatawan hanya sebanyak 993.029 orang. Kunjungan wisatawan mulai pulih dirasakan pada 2004 dengan jumlah kedatangan mencapai 1.458.309 orang. Namun, itu tidak berlangsung lama, karena 2005 Bali kembali diguncang bom kedua. Walaupun peristiwanya terjadi pada Oktober, kunjungan wisatawan ke Bali pada 2005 kembali turun, hanya menjadi 1.105.202 orang. ${ }^{16}$ Fakta tersebut menunjukkan bahwa dampak yang paling terasa dari sektor pariwisata terhadap kehidupan masyarakat Bali adalah sektor ekonomi. Dampak yang paling terasa dari pasang surutnya industri pariwisata adalah sektor ekonomi. Sementara untuk bidang lain walaupun memiliki dampak, namun pengaruhnya tidak langsung dirasakan masyarakat.

Dari hasil penelitian menunjukkan bahwa menurut responden ada beberapa dampak positif dari sektor pariwisata terhadap masyarakat. Pertama, adanya pembangunan masyarakat baik dalam bentuk sarana dan prasarana infrastruktur. Kedua, modernisasi, dalam sarana dan prasarana masyarakat, seperti: sarana penerangan, telekomunikasi. Ketiga, ada peningkatan pendapatan, dengan adanya sektor pariwisata menurut responden ada tambahan

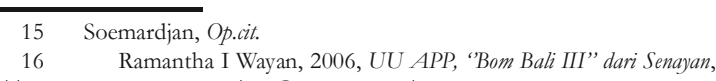

sumber pendapatan seperti dari hasil kerajinan ataupun dari sektor jasa. Keempat, peningkatan fasilitas sosial, dampak positif pada sarana sosial di masyarakat meningkat. Kelima, ada sebagian responden yang menganggap pariwisata memberi dampak positif bagi ritual keagamaan, yang dapat dikemas sebagai paket pariwisata.

Pariwisata selain memiliki dampak positif juga memiliki dampak negatif. Hasil penelitian menunjukkan ada beberapa dampak negatif dari pariwisata di masyarakat. Pertama, munculnya desakralisasi pura, dalam hal ini seringkali wisatawan menganggap masuk ke pura sebagai bagian dari paket wisata, padahal untuk masuk pura ada aturan-aturannya. Kedua, komersialisasi pura, kondisi ini terjadi karena adanya keinginan wisatawan agar dapat masuk ke pura sehingga ada pihak pengelola paket wisata yang menyertakan memasuki pura sebagai bagian dari paket wisatanya. Ketiga, pementasan benda sakral upacara, padahal benda sakral tersebut merupakan benda- benda yang memang disucikan dengan suatu upacara "penyucian" tertentu, yang fungsi dan penggunaannya semata-mata untuk tujuan suci dan ditempatkan pada tempat- tempat yang dipandang suci. Jenis-jenisnya meliputi: Pralingga, Arca, Pratima dan yang semacamnya. Keempat, pementasan tari sakral untuk pertunjukkan komersil, dalam hal ini menurut responden ada oknum-oknum yang dengan sengaja mengkomersialisasikan ritual adat dengan dalih sebagai bagian dari paket wisata. Kelima, terjadinya ketergantungan pada pihak asing. Ketergantungan dalam hal ini lebih terkait pada masalah ekonomi, ketika terjadi bom Bali I (2002) dan bom Bali II (2005) masyarakat mengalami ketergantungan kepada pihak asing (para wisatawan) baik dari luar negeri maupun dalam negeri. Dampak negatif kelima, lingkungan menjadi rusak, indikasi dari dampak ini dapat dilihat dengan semakin banyaknya penggunaan lahan subur untuk fasilitas penginapan (hotel) serta fasilitas lainnya.

Berdasarkan data tersebut dampak pariwisata terhadap keberadaan budaya lokal Bali lebih mengarah ke faktor ekonomi, sedangkan untuk tradisi dan adat istiadat tetap terpelihara melalui pelaksanaan ritual keagamaan (yajna) dalam kehidupan sehari-hari. Intensitas 
upacara ritual keagamaan tetap jalan di tengahtengah perkembangan pariwisata. Kondisi ini menunjukkan bahwa masyarakat Bali mencoba memadukan antara pemeliharaan tradisi dan ritual agama (tradisionalisasi) di satu sisi, dan di sisi lain juga melakukan proses toleransi dengan luar (internasionalisasi) kondisi ini seperti ini oleh Pitana (2005) disebut sebagai proses dynamic equilibrium, yaitu adanya kesadaran pada masyarakat Bali untuk senantiasa beradaptasi dan toleransi dengan pihak luar, namun di sisi lain ada kesadaran untuk tetap mempertahankan tradisinya. ${ }^{17}$

\section{E. Implementasi Pendidikan Agama dalam Mempertahankan Nilai-nilai Budaya Lokal dan Pengembangan Sektor Pariwisata Bali}

Manusia membutuhkan pendidikan dalam kehidupannya. Pendidikan merupakan usaha agar manusia dapat mengembangkan potensi dirinya melalui proses pembelajaran dan/atau cara lain yang dikenal dan diakui oleh masyarakat. Mengacu pada Undang-undang Nomor 20 tahun 2003 tentang Sistem Pendidikan Nasional Pasal 30 ayat (2) menyatakan bahwa pendidikan keagamaan berfungsi mempersiapkan peserta didik menjadi anggota masyarakat yang memahami dan mengamalkan nilai-nilai ajaran agamanya dan/atau menjadi ahli ilmu agama. Dengan demikian, pendidikan agama merupakan usaha untuk memperkuat 'sradha' dan 'bhakti' (iman dan takwa) terhadap Tuhan Yang Maha Esa.

Pendidikan agama Hindu merupakan upaya sadar dan terencana, menyiapkan peserta didik dalam mengenal, memahami, menghayati, hingga mengimani, bertakwa dan berakhlak mulia dalam mengamalkan ajaran agama Hindu. Pendidikan agama Hindu juga diarahkan untuk membangun kualitas mental pribadi peserta didik agar memiliki visi yang jelas, wawasan dan pengetahuan yang kontekstual, tujuan hidup yang jelas, komitmen terhadap nilai-nilai dan prinsip-prinsip hidup secara harmonis dan kreatif dalam masyarakat yang pluralistik, kepedulian terhadap lingkungan, berkarya sesuai dengan swadharyanya. Kualitas mental

17 Pitana. 2005. Sosiologi Pariwisata: Kajian Sosiologis Terbadap Struktur Sistem dan Dampak-dampak Pariwisata, Yogyakarta: Penerbit Andi tersebut menjadi penentu arah, penghela, motivator dan fasilitator dalam pengembangan swadarma hidupnya. Pendidikan agama Hindu membangun kesadaran akan persoalan bukan saja hidup sesudah mati tetapi juga apa yang harus diperbuat selama hidup di dunia ini. Kesadaran dibangun mulai dari kesadaran: (1) hidup untuk mencari makan, (2) hidup untuk mendapat rasa aman, (3) hidup untuk diterima oleh masyarakat, (4) hidup untuk mendapatkan status kehormatan, (5) hidup untuk menemukan makna hidup, dan (6) hidup untuk tidak hidup kembali (lahir kembali) sesuai dengan tingkatan hidupnya.

Tujuan pendidikan agama Hindu untuk menumbuhkembangkan dan meningkatkan 'Sradha' dan 'bhakti' (keimanan dan ketakwaan) dari peserta didik kehadapan Tuhan Yang Maha Esa melalui pemberian, pemupukan, penghayatan dan pengamalan ajaran agama, sehingga peserat didik mampu menjadi insan Hindu yang dinamis dan mampu mewujudkan cita-cita luhur beragama, yaitu 'mokashartam jagadhita' (kesejahteraan dan kebahagiaan hidup). Sementara, pelaksanaan pendidikan agama menurut Undang-undang Nomor 20 Tahun 2003 tentang Sistem Pendidikan Nasional Pasal 30 ayat (3), bahwa pendidikan keagamaan dapat diselenggarakan pada jalur pendidikan formal, nonformal, dan informal. Mengacu pada pada landasan legal formal ini, maka pelaksanaan pendidikan agama dapat dilakukan pada lembaga pendidikan formal (sekolah) dan lembaga nonformal/informal. Pola pendidikan agama di masyarakat Bali tidak jauh berbeda dengan yang digariskan oleh Undang-undang, yaitu dilakukan secara formal dan informal.

Sumber utama dan titik berat kepariwisataan bertumpu pada kebudayaan yang dijiwai oleh agama Hindu serta keindahan alam. Kepariwisataan tidak terbatas pada usaha kerajinan tangan, pertanian dan budaya serta kesenian tetapi justru merupakan usaha komplementer yang sangat komplek dan menyeluruh, baik dalam bentuk pelayanan seperti akomodasi dan transportasi serta pelayanan jasa-jasa lainnya. Langkah-langkah guna menunjang usaha kepariwisataan antara lain melalui pengembangan objek wisata serta kegiatan produksi barang kerajinan untuk 
cindera mata, di samping tetap menjaga stabilitas keamanan dan kelestarian lingkungan hidup.

Kondisi ini tentunya tidak lepas dari berbagai faktor yang ada di masyarakat Bali yang mampu berperan sebagai modal sosial dalam mempertahankan nilai-nilai tradisinya di masyarakat. Fukuyama menyatakan bahwa modal sosial merupakan norma informal yang mendorong kerja sama antara individu dalam masyarakat. Jadi, modal sosial menciptakan suasana lingkungan hidup yang saling mempercayai dan menghormati antaranggotanya. Lebih lanjut Fukuyama menjelaskan bahwa modal sosial lebih mengacu pada adanya: (1) trust (kepercayaan), hal ini sangat penting karena adanya kepercayaan maka hubungan akan menjadi semakin kuat, semakin besar trust ini dibangun maka semakin besar networking dari trust itu sendiri, (2) informal, menjadi dasar terbentuknya hubungan yang kuat dan berada dalam konteksa masyarakat yang beradab, dan (3) networking (jejaring).

Modal sosial dalam konteks ini adalah adanya trust (kepercayaan) yang dibangun oleh masyarakat Bali yang mengacu pada tatanan nilai-nilai (norma) yang akan membentuk jejaring (networking) di masyarakat. Dalam konteks ini nilai-nilai dasar yang menjadi pijakan masyarakat Bali adalah gambaran hubungan yang harmonis antara Tuhan dengan manusia, manusia dengan manusia dan manusia dengan alam. Norma keharmonisan yang menjadi landasan dalam hubungan antarmanusia dengan sesamanya, manusia dengan Tuhan dan manusia dengan lingkungan alamnya merupakan nilai-nilai yang menjadi dasar terciptanya trust (kepercayaan) di masyarakat. Sistem trust inilah yang menjadi perekat masyarakat Bali, sehingga antarwarga masyarakat tercipta jejaring (networking) dalam suatu lembaga sosial.

Bentuk lembaga sosial di Bali beragam, dalam sistem pemerintahan desa dikenal dua sistem, yaitu sistem pemerintahan desa dinas dan desa adat. Desa dinas merupakan lembaga pemerintah yang berkaitan langsung dengan masalah masalah administrasi kepemerintahan. Desa ini dikepalai oleh seorang lurah/Kepala Desa/Perbekel. Desa dinas merupakan ujung tombak pembangunan di tingkat bawah yang merupakan perpanjangan dari tangan pemerintah daerah yang mempunyai wewenang dan tanggung jawab pemerintahan dan pembangunan di wilayahnya. Sementara desa adat adalah sistem pemerintahan yang terjalin secara fungsional dan bukan secara struktural. Hal tersebut tercermin dari fungsi pokok dari desa adat adalah di bidang adat dan agama yang sudah menjadi suatu tradisi interaksi antarsesama warga dalam satu lembaga dengan aturanaturan sendiri yang tertuang di dalam Awig-awig. Desa adat dapat dibedakan menjadi dua pola, yaitu: (1) desa adat dengan pola pimpinan tunggal, dengan aparatnya yang terdiri dari Bendesa Adat, Penyarikan, Petajuh, Kesinoman, dan (2) desa adat yang pola pimpinannya majemuk, dengan aparat aparat yang terdiri dari Kelian Desa Adat, Penyarikan, Bendahara Desa, Sekretaris Desa, Juru Arah.

Lembaga lembaga lain yang berada di bawah naungan desa adat adalah sebagai berikut. Pertama, Banjar Adat, yang merupakan kesatuan sosial yang lebih kecil lingkupnya dari desa adat dan merupakan bagian dari desa adat, di mana pimpinannya adalah Kelian Desal Kelian Adat. Kedua, Subak, merupakan lembaga masyarakat hukum adat yang bersifat agraris religius, yang terdiri dari petani penggarap sawah atau ladang/kebun dalam wilayah desa adat tertentu dan diikat oleh awig-awig tersendiri serta menyungsung Pura sendiri yang disebut Pura Subak/Budugul/Ulunsuwi. Ketiga, Sekaa, yaitu organisasi yang dibentuk secara sukarela berdasarkan profesi dengan tujuan-tujuan tertentu, baik permanen maupun sementara. Sekaa permanen seperti sekaa Gong, Tarunateruni. Sekaa yang sifatnya sementara adalah seperti sekaa Manyi, Memula, Sekaa kopi, dan sebagainya.

Secara struktur organisasi lembaga sosial di atas memiliki karakteristik masing-masing, namun secara fungsional memiliki saling keterkaitan dalam pelaksanaan ritual keagamaan. Kehidupan sosial yang penuh diliputi pola upacara keagamaan yang beragam merupakan ciri khas masyarakat Bali, kondisi demikian diistilahkan sebagai pluralistic collectivism, ${ }^{18}$ yaitu suatu masyarakat yang terdiri dari berbagai kesatuan yang saling terkait akan tetapi tetapi

18 Geerzt Clifford. 1964. Tibingan: Sebuah Desa di Bali, dalam buku Koentjaraningrat (ed.) Masyarakat Desa di Indonesia Masa Ini. Jakarta: Badan Peenrbit Fakultas Ekonomi UI. 
masing-masing kesatuan memiliki fungsi khusus sendiri.

Keberadaan beragam lembaga sosial tersebut merupakan media jejaring warga masyarakat dalam mengembangkan pariwisata di satu sisi, dan di sisi lain sebagai media jejaring dalam pelaksanaan ritual keagamaan. Dengan kata lain lembaga-lembaga tradisional masyarakat Bali dan ritual upacara keagamaan merupakan modal sosial yang dimiliki warga masyarakat Bali. Modal sosial inilah yang membentuk sistem norma-norma dan nilai-nilai yang menjadi pengikat bersama, membangung trust (kepercayaan) antarwarga sehingga mampu bekerja sama dan saling membantu dalam berbagai aktivitas sosial keagamaan, dan di sisi lain berperan sebagai media terbentuknya jejaring (networking) antarwarga masyarakat. Implementasi pendidikan agama dalam konteks pengembangan pariwisata tetap terus berjalan yang dibingkai oleh proses pelembagaan (institutionalization) ritual agama sebagai komponen modal sosial masyarakat Bali.

\section{F. Penutup}

Nilai-nilai keagamaan teraplikasi dalam berbagai wujud kebudayaan, mengindikasikan bahwa pola pengajaran dan pendidikan agama selain didapat dari lembaga pendidikan (sekolah ataupun pasraman) juga diperoleh dari pelaksanaan ritual dan tradisi yang ada dan telah menjadi norma-norma di masyarakat. Norma-norma tersebut mengalami proses pelembagaan (institutionalization), yaitu proses yang dilewati oleh suatu norma kemasyarakatan untuk menjadi bagian dari salah satu lembaga kemasyarakatan.

Pariwisata Bali berdampak positif dan negatif. Dampak positifnya yang ada antara lain meningkatnya taraf hidup masyarakat terutama yang bergerak di bidang yang ada hubungannya dengan kepariwisataan. Sedangkan dampak negatif yang muncul adalah terjadinya komersialisasi, komodifikasi dan profanisasi, dalam konteks ini dampak tersebut lebih mengarah ke faktor ekonomi. Dengan kata lain dampak pariwisata terhadap keberadaan budaya lokal Bali lebih mengarah ke faktor ekonomi, sedangkan untuk tradisi dan adat istiadat tetap terpelihara melalui pelaksanaan ritual keagamaan (yajna) dalam kehidupan sehari-hari. Kehidupan sosial yang penuh diliputi pola upacara keagamaan yang beragam merupakan ciri khas masyarakat Bali, yaitu pluralistic collectivism, yaitu suatu masyarakat yang terdiri dari berbagai kesatuan yang saling terkait akan tetapi tetapi masing-masing kesatuan memiliki fungsi khusus sendiri. Keberadaan beragam lembaga sosial tersebut merupakan media jejaring warga masyarakat dalam mengembangkan pariwisata di satu sisi, dan di sisi lain sebagai media jejaring dalam pelaksanaan ritual keagamaan.

\section{Daftar Pustaka}

Ambara, Alit. 2001. Proyek Bank Dunia MemBali-Kan Bali. http://mkb.kerjabudaya. org/. html. (diakses tanggal 1 Juni 2006).

Durkheim, Emile. 1965. The Elementery Forms of the Religious Life. New York: Free Press.

Erawan, Nyoman. 2000. Pertumbuban Pariwisata Bali Sebaiknya Dibatas. Jakarta: Harian Kompas 9 November 2000.

Fadhilah, A. 2004. Partisipasi Pemimpin Pondok Pesantren dalam Pembangunan dan Perubahan Sosial di Kota Depok. Jakarta: Lembaga Penelitian Universitas Islam Negeri (UIN) Syarif Hidayatullah Jakarata.

2005. Budaya Politik Kyai di Pedesaan: Studi Kasus Kyai Pesantren di Kabupaten Pekalongan. Tesis Program Studi Sosiologi Pedesaan Sekolah Pascasarjana IPB.

Fukuyama. F. 2001. SocialCapital: Civil Society and development. Third World quarterly. Vol. 22 No. 01.

Geerzt, Clifford. 1964. Tihingan: Sebuah Desa di Bali, dalam buku Koentjaraningrat (ed.) Masyarakat Desa di Indonesia Masa Ini, Jakarta: Badan Penerbit Fakultas Ekonomi UI.

Horikoshi,Hiroko.1987. Kyaidan Perubahan Sosial. Jakarta: Perhimpunan Pengembangan Pesantren dan Masyarakat (P3M).

Ismuha, dkk. 1996. Ulama Aceh dalam Perspektif Sejarah (dalam buku Agama dan Perubahan Sosial oleh Taufik A. (ed). Jakarta: PT Raja Grafindo.

Jackson, Karl D. 1990. Kewibawaan Tradisional. Islam dan Pemberontakan: Kasus Darul Islam Jawa Barat. Jakarta: Pustaka Utama Grafiti. 
Koentjaraningrat. 1990. Pengantar Ilmu Antropologi. Jakarta: PT Rineka Cipta.

Kurasawa, Aiko. 1993. Mobilitas dan Kontrol Sosial: Studi Tentang Perubahan Sosial di Pedesaan Jawa 1942-1945 (terjemahan dari Mobilization and Control oleh Hermawan Sulistyo). Jakarta: PT Gramedia Widiasarana Indonesia

Lietaer, B. 2003. Sustaining Cultural Vitality in a Globalizing World: The Balinese Example. International Journal of Social Economics, Vol. 30 No. 92003. (Kedinamisan Kebidupan Budaya yang Keberlanjutan Dalam Era Globalisasi Dunia: Masyarakat Bali sebagai Contoh Konsep, http://www.appropriate-economics.org/ asia/indonesia/Sustaining_Cultural_ Vitality_Bhs_Indonesia. Diakses tanggal 1 Juni 2006

Nugraha Iskandar P. 2005. Masa Lalu dan Tantangan Masa Depan Bali, Jakarta: Harian Kompas 15 Oktober 2005.

Picard, M. 1996. Bali: Cultural Tourism and Touristic Culture, Singapore: Archipelago Press.

Pitana. 2005. Sosiologi Pariwisata: Kajian Sosiologis Terbadap Struktur, Sistem dan Dampakdampak Pariwisata, Yogyakarta: Penerbit Andi.
Ramantha, I Wayan. 2006. UU APP, "Bom Bali III" dari Senayan, http:/ / www.mail archive. com/ppi@freelists.org/msg27321.html.

Sanderson Stephen K. 2000. Makro Sosiologi : Sebuah Pendekatan Terbadap realitas Sosial (terjemahan dari Makro Sosiologi oleh Farid Wajidi), Jakarta: P'T Raja Grafindo.

Soemardjan Selo dan S. Soemardi. 1964. Setangkai Bunga Sosiologi. Jakarta: Lembaga Penerbit Fakultas ekonomi Universitas Indonesia.

Thomas F. O'dea. 1987. Sosiologi Agama: Suatu Pengenalan Awal (terjemahan dari The Sociology of Religion: oleh Tim penerjemah Yasogama). CV Rajawali, Jakarta.

Tim Penyusun PHDI. 2005. Buku Pelajaran Agama Hindu, Surabaya: Penerbit Paramita.

Tisna I Gusti Raka Panj. 2005. Sekilas Tentang Dinamika Seni Pertunjukan Tradisional Bali Dalam Konteks Pariwisata Budaya, http://www.mspi.org/index.

Undang-Undang Republik Indonesia Nomor 20 Tahun 2003 Tentang Sistem Pendidikan Nasional. 
